\title{
Primary peritoneal carcinoma and ovarian carcinoma - a ten-year comparative analysis
}

\author{
Primární peritoneální karcinom a ovariální karcinom - desetiletá \\ komparativní analýza
}

\author{
Dahiya A. ${ }^{\text {, }}$, Peedicayil A. ${ }^{1}$, Singh A. ${ }^{2}$, Thomas A. ${ }^{1}$, Thomas V. ${ }^{1}$, Chandy R. G. ${ }^{1}$, Sebastian A. ${ }^{1}$ \\ 1 Department of Gynaecologic Oncology, Christian Medical College, Vellore, India \\ ${ }^{2}$ Department of Medical Oncology, Christian Medical College, Vellore, India
}

\begin{abstract}
Summary
Background: Primary peritoneal carcinoma (PPC) at presentation often masquerades as epithelial ovarian carcinoma (OC) but behaves different with respect to treatment response, recurrence patterns and has inferior outcomes. The objective of this study is to compare the clinicopathological features and survival outcomes of PPC and OC. Methods: Prospectively maintained database of patients presenting to the gynecologic oncology department at a tertiary hospital was reviewed between $1^{\text {st }}$ January 2010 and 31 $1^{\text {st }}$ December 2020. A comparative analysis of high-grade serous stage III/IV PPC and OC was done. Demographics, treatment details, complications and survival outcomes were collected from electronic medical records. Results: 151 OC and 69 PPC patients were included. A higher proportion of women with PPC had reduced performance status prior to hysterectomy with salpingo-oophorectomy, a shorter symptom to treatment interval, and large volume ascites. A significantly lower number of women with PPC ( 4.3 vs. $46.1 \%$; $P<0.001)$ underwent primary cytoreduction, had a lower median surgical complexity score ( 3 vs. $4 ; \mathrm{P}<0.001$ ) but higher recurrence rates $(66.7$ vs. $47.0 \%$; $\mathrm{P}=0.041$ ) as compared to the patients with $\mathrm{OC}$. The median progression-free survival (PFS) was 18 (15-20) months in PPC and 23 (17-28) months in OC patients (log-rank $P=0.034$ ), while the median overall survival (OS) was similar (44 vs. 48 months; log-rank $P=0.696$ ). The presence of extraperitoneal disease and interval cytoreduction was associated with shorter PFS. Suboptimal cytoreduction and delay in adjuvant chemotherapy beyond 6 weeks post-surgery was associated with reduced OS. Conclusion: PPC is an aggressive disease with lower PFS compared to OC. Commonly presenting with large volume carcinomatosis, it is not amenable for primary cytoreduction, making the usage of neoadjuvant chemotherapy a common practice and pragmatic approach.
\end{abstract}

Key words

primary peritoneal carcinoma - ovarian carcinoma - survival outcomes - clinicopathological characteristics
The authors declare they have no potential conflicts of interest concerning drugs, products, or services used in the study.

Autoři deklarují, že $v$ souvislosti s předmětem studie nemaji žádné komerční zájmy.

The Editorial Board declares that the manuscript met the ICMJE recommendation for biomedical papers.

Redakční rada potvrzuje, že rukopis práce splnil ICMJE kritéria pro publikace zasílané do biomedicínských časopisů.

$\equiv^{\circ}$

Ass. Prof. Ajit Sebastian, MD

Department of Gynaecologic Oncology

Christian Medical College

Vellore

Tamil Nadu-632004

India

e-mail: sebastian.ajit@gmail.com

Submitted/Obdrženo: 27. 5. 2021

Accepted/Přijato: 8. 7. 2021

doi: $10.48095 /$ ccko202263 


\begin{abstract}
Souhrn
Východiska: Primární peritoneální karcinom (primary peritoneal carcinoma - PPC) se často projevuje jako epiteliálne ovariální karcinom (ovarian carcinoma - OC), ale chová se jinak ve smyslu odpovědi na léčbu a výskytu rekurence a má horší výsledky. Cílem této studie je srovnání klinicko-patologických vlastností a výsledků vztahujících se k přežití u PPC a OC. Metody: Byla revidována prospektivně vedená databáze pacientek, které se dostavily na oddělení gynekologické onkologie specializované nemocnice v období od 1. ledna 2010 do 31. prosince 2020. Byla provedena komparativní analýza vysokostupňových serózních PPC a OC stadia III/IV. Z elektronických lékařských záznamů byly shromážděny demografické charakteristiky a data o léčbě, komplikacích a výsledcích z hlediska přežití. Výsledky: Do studie bylo zahrnuto 151 pacientek s OC a 69 pacientek s PPC. U žen s PPC bylo vyšší procento těch, které měly před hysterektomií se salpingo-ooforektomií snížený výkonnostní status, kratší interval od symptomů $k$ léčbě a velký objem ascitu. Významně méně žen s PPC $(4,3$ vs. $46,1 \% ; p<0,001)$ podstoupilo primární cytoredukci a mělo nižší medián skóre operační komplexity ( 3 vs. $4 ; p<0,001)$, ale vyšší procento rekurence $(66,7$ vs. $47,0 \% ; p=0,041)$, a to v porovnání s pacientkami s OC. Medián přežití bez progrese (progression-free survival - PFS) byl u pacientek s PPC 18 (15-20) měsíců a u OC 23 (17-28) měsíců (log-rank $p=0,034)$, zatímco medián celkového přežití (overall survival - OS) byl podobný (44 vs. 48 měsíců; log-rank $p=0,696)$. Extraperitoneální onemocnění a intervalová cytoredukce byla spojena s kratším PFS. Při suboptimální cytoredukci a opožděné adjuvantní chemoterapii podané déle za > 6 týdnů od operace bylo pozorováno kratší OS. Závěr: PPC je agresivní onemocnění, u kterého je v porovnání s OC kratší PFS. Jelikož se PPC obvykle projevuje karcinomatózou o vysokém objemu, není u něj vhodná primární cytoredukce. Obvyklým postupem a zároveň pragmatickým přístupem k léčbě je využití neoadjuvantní chemoterapie.
\end{abstract}

\title{
Klíčová slova
}

primární peritoneální karcinom - ovariální karcinom - výsledky přežití - klinicko-patologické charakteristiky

\section{Introduction}

Primary peritoneal carcinoma (PPC) is an aggressive malignant epithelial tumor involving diffuse abdominal peritoneal carcinomatosis, placed alongside epithelial ovarian and fallopian tube cancer under the broader spectrum of Mullerian carcinoma. It bears close histological and clinical resemblance to epithelial ovarian carcinoma $(O C)$ but with the absence of a demonstrable primary ovarian tumor [1,2].

PPC occurs at approximately one tenth the frequency of epithelial OC with an age-adjusted incidence rate of 0.68 per 100,000, respectively [1]. Initially considered a rare entity, PPC incidence has shown a dramatic increase over the last decade and is usually associated with late diagnosis and a dismal prognosis [1-4]. While earlier reports indicated that PPC was due to malignant transformation of coelomic epithelium, recent research suggests serous tubal intraepithelial carcinoma (STIC) as a potential precursor lesion of ovarian, fallopian tube, and peritoneal carcinoma $[5,6]$. However, many studies have not found any STIC lesion in patients with PPC, even on application of SEE-FIM (sectioning and extensively examining the fimbriated end of the fallopian tube) protocol. Thus, PPC may have a multiclonal origin [7].

Opinions remain divided on whether PPC is a distinct entity or a phenotypic variant of OC. There are some differences in etiological factors, risk factor profiles, tumor biology, and treatment responses $[6,8,9]$. Studies analyzing clinical outcomes have produced inconsistent results with the survival of PPC patients being better [10], similar [11-16], or worse [4,9,17-19] compared to patients with advanced serous OC.

There are few descriptive studies on PPC, and most of them have focused on the Western population. The study intends to better understand this disease entity by exploring its various aspects in an Indian setup. As this is a retrospective analysis, we have used the Gynecologic Oncology Group (GOG) '93 criteria to define PPC:

- both ovaries of normal size or enlarged by benign process;

- extra ovarian site involvement greater than ovarian surface involvement;

- ovarian component with cortical tumor invasion less than $5 \times 5 \mathrm{~mm}$ [2].

The primary objectives of our study were:

- to compare and analyze the clinicopathological characteristics of primary peritoneal carcinoma (PPC) and ovarian carcinoma $(\mathrm{OC})$;

- to determine and compare the median PFS and median OS in both groups.

The secondary objective was to determine the prognostic factors inde- pendently affecting survival and disease progression.

\section{Materials and methods}

A retrospective comparative analysis was done between PPC and OC patients after obtaining Institutional Review Board approval. A prospectively maintained clinical database was reviewed for patients who started treatment for a diagnosis of OC and PPC between $1^{\text {st }}$ January 2010 and $31^{\text {st }}$ June 2020. Patient consent was waived off as it was a retrospective study. Patients were followed up until $31^{\text {st }}$ December 2020.

\section{Inclusion criteria}

- All patients with FIGO (International Federation of Gynecology and Obstetrics) stage III/IV PPC with high-grade serous histology. Patients underwent treatment in our institution - primary debulking surgery (PDS) or neoadjuvant chemotherapy (NACT) followed by interval debulking surgery (IDS). Adjuvant treatment was taken either in our institute or if taken outside, details were known.

- GOG '93 criteria were used on imaging before treatment to define PPC followed by surgico-pathological correlation to confirm the diagnosis as done in previously published data $[2,3,17]$.

- The comparison group included patients with high-grade serous ovarian carcinoma, FIGO stage III/IV. 


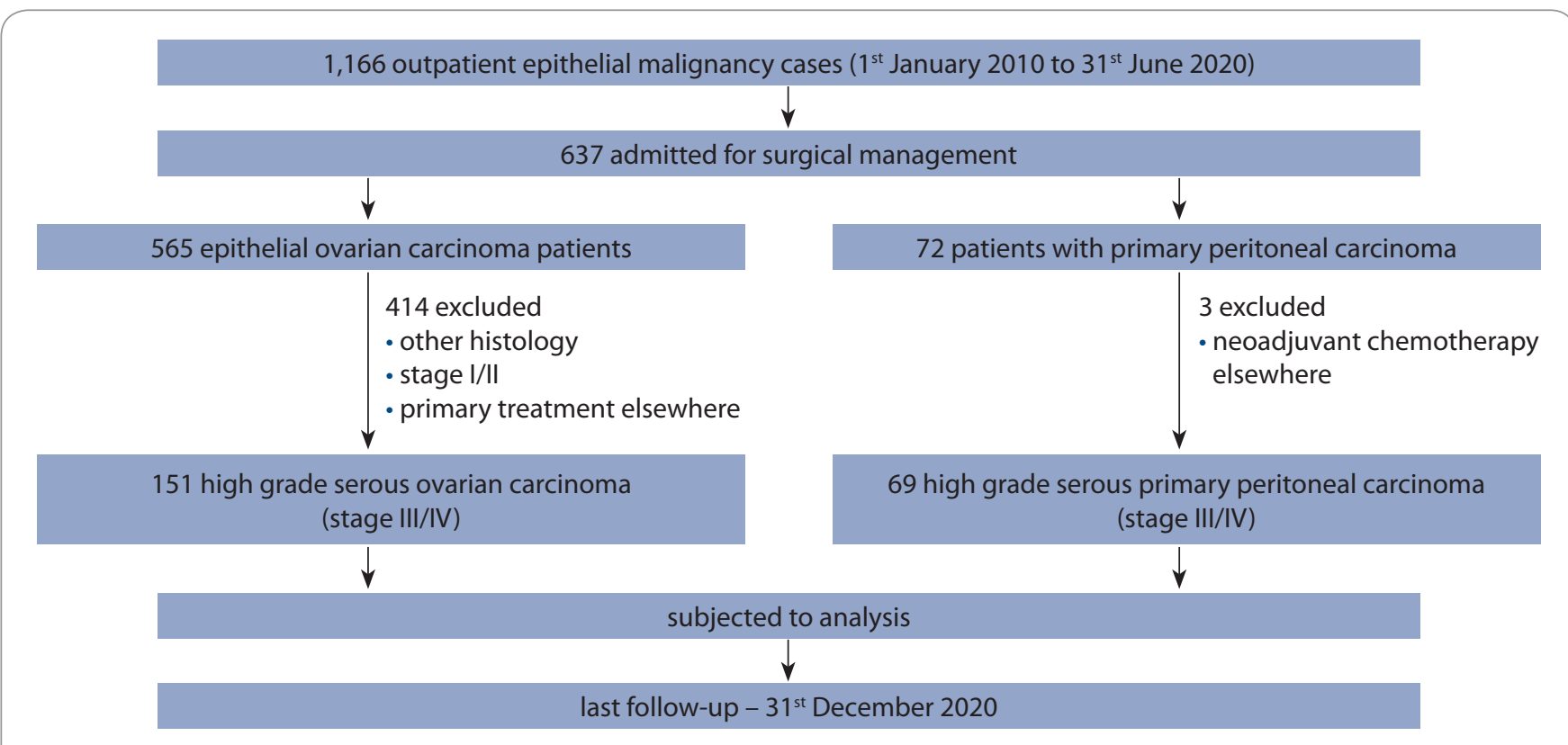

STROBE - strengthening the reporting of observational studies in epidemiology

Scheme 1. STROBE flow diagram highlighting ovarian carcinoma and primary peritoneal carcinoma patient selection using the Gynecologic Oncology Group '93 criteria.

\section{Exclusion criteria}

All patients with PPC/OC early-stage disease, non-serous histology, or primary treatment taken outside of our institution were excluded.

\section{Sample size calculation}

A case-control study by Eisenhauer EL [18] was used as a reference to calculate the sample size based on statistically different OS (PPC HR 1.54; P $<0.001$ ) in the two groups (PPC, OC). We were required to analyze $122 \mathrm{OC}$ and 61 PPC patients ( $2: 1$ ratio) to achieve clinically relevant results of statistical significance.

\section{Data analysis}

The data were entered and analyzed using SPSS 25 (IBM, Armonk, NY, USA) software. Independent t-test was used for continuous variables (age, body mass index, performance status, serum albumin, symptom to treatment interval, CA-125 levels, peritoneal carcinomatosis index, Aletti's surgical complexity score) and Chi-square test for categorical variables (last child birth > 35 years, family history, tubal ligation, previous hysterectomy, ascites, adjuvant treatment, $B R C A$ status, platinum response).
Statistical significance was placed at $\mathrm{P}<0.05$

Adjuvant treatment was considered delayed if the time interval between surgical cytoreduction and the first cycle of adjuvant chemotherapy was more than 6 weeks $[20,21]$.

PFS was calculated from the date of starting treatment (first chemotherapy cycle or primary surgery) to the first recurrence/start of the second-line treatment. Recurrence was defined as radiological evidence of disease. OS was calculated from the date of the first treatment to death due to any cause. Patients without an event were censored at the date of the last follow-up.

Kaplan-Meier curves were drawn, and the log-rank test was used for comparison. Univariate Cox regression was used to assess the effect of tumor site (ovarian/peritoneal), age, Eastern Cooperative Oncology Group (ECOG) performance status, treatment modality (PDS/IDS), residual tumor, and adjuvant treatment on survival followed by multivariate analysis.

\section{Results}

During this study period, 1,166 patients with epithelial malignancy were seen in the outpatient Department of Gynecologic Oncology at our hospital, out of which 637 (565 patients with OC and 72 with PPC) were admitted for surgical management (Scheme 1). After excluding patients who did not fit the inclusion criteria, 151 primary OC and 69 PPC cases of high-grade serous stage III/IV disease were included in the study. The demographic and clinical characteristics of patients are presented in Tab. 1.

At presentation, patients with PPC had an inferior performance status $(P<0.001)$, higher rates of prior hysterectomy with salpingo-oophorectomy $(P=0.026)$, shorter symptom to treatment interval $(P=0.028)$, and large volume ascites $(P<0.001)$. OC patients with a history of hysterectomy with bilateral salpingo-oophorectomy were found to have ovarian/fallopian tube remnant tissues on surgicopathological review after surgery, while no such remnants were found in PPC patients with a similar history. BRCA1 and BRCA2 gene mutation testing was done in $32 \mathrm{OC}$ and 15 PPC patients (as per consent given), out of which 7 (21.9\%) OC and 4 (26.7\%) PPC patients were found to be positive for either BRCA1 or BRCA2 $(\mathrm{P}=0.823)$. 
Tab. 1. Univariate analysis comparing the baseline demographic and clinical characteristics of ovarian carcinoma and primary peritoneal carcinoma.

\begin{tabular}{|c|c|c|c|}
\hline & $O C(N=151)$ & PPC (N = 69) & P-value \\
\hline Mean age (years $\pm S D$ ) & $49.0( \pm 10.0)$ & $52.0( \pm 9.0)$ & 0.119 \\
\hline Mean BMI $\left(\mathrm{kg} / \mathrm{m}^{2} \pm \mathrm{SD}\right)$ & $24.0( \pm 4.0)$ & $25.3( \pm 5.0)$ & 0.861 \\
\hline Median parity $( \pm S D)$ & $2(0-7)$ & $3(0-7)$ & 0.311 \\
\hline Last child birth at $>35$ years & $11(7.2 \%)$ & $7(10.4 \%)$ & 0.365 \\
\hline Family h/o breast/ovarian cancer & $12(7.9 \%)$ & $8(11.6 \%)$ & 0.258 \\
\hline $\mathrm{H} /$ o hysterectomy with BSO & $2(1.3 \%)$ & $9(13.0 \%)$ & 0.026 \\
\hline H/o tubal ligation & $69(45.4 \%)$ & $29(42.0 \%)$ & 0.377 \\
\hline Median ECOG status ( \pm SD) & $1(0-3)$ & $1(0-3)$ & $<0.001$ \\
\hline Mean CA-125 (U/mL \pm SD) & $1,680( \pm 2,290)$ & $2,171( \pm 2,900)$ & 0.100 \\
\hline Severe ascites (> $3 \mathrm{~L})$ & $94(48.0 \%)$ & $64(92.7 \%)$ & $<0.001$ \\
\hline Mean symptom to treatment interval (months \pm SD) & $4( \pm 4.5)$ & $2( \pm 1.9)$ & 0.028 \\
\hline Mean albumin levels ( $g / d L \pm S D)$ & $3.8( \pm 0.5)$ & $3.5( \pm 0.5)$ & 0.433 \\
\hline
\end{tabular}

Tab. 2. Univariate analysis comparing the treatment received, surgical complexity, adjuvant chemotherapy received by ovarian carcinoma and primary peritoneal carcinoma patients.

\begin{tabular}{|c|c|c|c|}
\hline & $O C(N=151)$ & PPC (N = 69) & P-value \\
\hline Primary cytoreduction & $70(46.1 \%)$ & $3(4.3 \%)$ & $<0.001$ \\
\hline Median number of NACT cycles ( \pm SD) & $3(2-6)$ & $3(2-6)$ & 0.410 \\
\hline Intraoperative $\mathrm{PCl}$ score $( \pm \mathrm{SD})$ & $9.4( \pm 4.8)$ & $7.8( \pm 5.7)$ & 0.030 \\
\hline Median Aletti score & $4(1-12)$ & $3(1-8)$ & $<0.001$ \\
\hline Optimal cytoreduction & $120(79.5 \%)$ & $52(75.3 \%)$ & 0.171 \\
\hline \multicolumn{4}{|l|}{ Additional procedures } \\
\hline - lymph node dissection & $69(45.4 \%)$ & $17(24.6 \%)$ & 0.002 \\
\hline - diaphragm stripping/resection & $35(23.0 \%)$ & $12(17.4 \%)$ & 0.222 \\
\hline - small bowel resection/anastomosis & $10(6.6 \%)$ & $0(0 \%)$ & 0.022 \\
\hline - large bowel resection/anastomosis & $29(19.1 \%)$ & $1(1.45 \%)$ & 0.002 \\
\hline - bowel diversion & $19(12.5 \%)$ & $1(1.45 \%)$ & 0.004 \\
\hline - peritonectomy & $39(25.7 \%)$ & $12(17.4 \%)$ & 0.118 \\
\hline - splenectomy & $5(3.29 \%)$ & $1(1.45 \%)$ & 0.101 \\
\hline - HIPEC & $3(1.9 \%)$ & $7(10.1 \%)$ & 0.029 \\
\hline - adjuvant chemotherapy & 137 (90.1\%) & $61(88.4 \%)$ & 0.512 \\
\hline - delayed /no adjuvant & $50(33.1 \%)$ & $20(28.9 \%)$ & 0.261 \\
\hline
\end{tabular}

The most common site involved in stage IVb OC was liver parenchyma, followed by supraclavicular node and ab- dominal wall, while the one patient with stage IVb PPC had supraclavicular node involvement.
Tab. 2 highlights the characteristics of the treatment received. A significantly higher number of patients with 
Tab. 3. Univariate analysis comparing the features of disease recurrence in ovarian carcinoma and primary peritoneal carcinoma.

\begin{tabular}{|c|c|c|c|}
\hline & $O C(N=151)$ & PPC $(N=69)$ & P-value \\
\hline Median follow-up (months) & $23(1-62)$ & $23(4-60)$ & 0.684 \\
\hline Recurrence/progression & $71(47.0 \%)$ & $46(66.7 \%)$ & 0.041 \\
\hline Platinum resistant relapse & $8(12.7 \%)$ & $2(3.0 \%)$ & 0.145 \\
\hline Secondary cytoreduction & $5(3.29 \%)$ & $1(1.45 \%)$ & 0.332 \\
\hline \multicolumn{4}{|l|}{ Sites of recurrence } \\
\hline - peritoneum (parietal/bowel serosa/pelvic visceral) & $40(26.5 \%)$ & $30(43.4 \%)$ & 0.080 \\
\hline - lymph nodes & $31(20.5 \%)$ & $10(14.5 \%)$ & 0.011 \\
\hline - bowel mesentery & $20(13.2 \%)$ & $11(15.1 \%)$ & 0.124 \\
\hline - pelvic/local recurrence & $20(13.2 \%)$ & $4(5.7 \%)$ & 0.014 \\
\hline - abdominal wall & $2(1.3 \%)$ & $1(1.4 \%)$ & 0.412 \\
\hline - upper abdomen (biliary tract, spleen, lesser sac, stomach) & $12(7.9 \%)$ & $7(10.4 \%)$ & 0.321 \\
\hline - distant ( brain, bone, lung) & $4(2.6 \%)$ & $1(2.5 \%)$ & 0.101 \\
\hline
\end{tabular}

PPC underwent neoadjuvant chemotherapy followed by interval cytoreduction $(\mathrm{P}<0.001)$ compared to OC patients with rates of optimal debulking (residual disease $<1 \mathrm{~cm}$ ) being similar. The median gap between the last neoadjuvant and first adjuvant chemotherapy of approximately 8 weeks was similar in both groups. The number of patients receiving no/delayed adjuvant treatment due to any reason (delayed post-operative recovery, default, logistic issues) also did not differ significantly between the two groups.

The Aletti surgical complexity score was higher for OC patients $(P<0.001)$ considering the higher rate of primary cytoreduction. Patients with carcinoma ovary were found to have a significantly higher rate of lymph node dissection $(P=0.002)$, bowel resection/anastomosis $(P=0.022)$, and bowel diversion $(P=0.004)$. Hyperthermic intraperitoneal chemotherapy (HIPEC) post optimal interval cytoreduction was given to 3 (1.9\%) OC and 7 (10.0\%) PPC patients $(P=0.029)$.

Of those who had suboptimal cytoreduction, the most common sites of residual disease were the bowel serosa/mesentery and diaphragm in both groups. Forty-six (66.7\%) PPC patients had disease recurrence/progression within the study period compared to
71 (47.0\%) OC patients ( $P=0.041)$. Secondary cytoreduction was possible in only 5 (3.29\%) OC and one (1.45\%) PPC patient at the time of recurrence. Eight (12.7\%) OC patients were found to have a platinum-resistant disease recurrence (within 6 months of completion of adjuvant chemotherapy) compared to $2(3 \%)$ patients in the PPC group ( $P=0.145)$.

On subgroup analysis, comparing patients with IDS across the groups, the Aletti surgical complexity score was significantly higher for OC. No significant difference was found in other treatment variables.

Parietal peritoneum and bowel serosa followed by lymph nodes were the most commonly involved sites in OC recurrence, while parietal/pelvic visceral peritoneum and bowel mesentery involvement was more common in PPC recurrence (Tab. 3).

\section{Survival analysis}

PPC and OC patients had similar OS (44 vs. 48 months; $P=0.696$ ) at a median follow-up of 23 (4-60) months and 23 (1-62) months, respectively, while PFS was inferior for PPC patients (18 vs. 23 months, $P=0.034$ ) as highlighted in Fig. 1. At 3 years, the estimated PFS was $18 \%$ for the PPC group and $39 \%$ for the OC group, while the estimated OS was $59 \%$ and $66 \%$, respectively.
In the univariate Cox regression model with $\mathrm{OS}$ as the endpoint, increasing age (HR 1.03; $P=0.031)$, poor performance status (HR 1.82; $P=0.005)$, interval cytoreduction (HR 2.24; $P=0.009$ ), suboptimal debulking (HR 1.85; $\mathrm{P}<0.001$ ) and delayed or no adjuvant treatment ( $H R$ 2.00; $P=0.006)$ increased the risk of early death.

In the univariate Cox regression model with PFS as the endpoint, PPC (HR 1.48; $P=0.032)$, increasing age (HR 1.02; $P=0.036)$, interval cytoreduction (HR 2.55; $P<0.001)$, sub-optimal debulking (HR 1.46; $P<0.001)$ and higher stage (HR 1.59; $P<0.001)$ increased the risk of progression.

In multivariate Cox regression analysis (Tab. 4), after controlling for independent variables, suboptimal cytoreduction (HR 2.62; P $<0.001$ ) and delayed or no adjuvant treatment (HR 1.69; $P=0.044$ ) had a significant impact on OS while a shorter PFS was associated with interval debulking surgery (HR 2.18; $P=0.002)$, suboptimal debulking (HR 1.4; $\mathrm{P}<0.001)$ and higher stage (HR 1.446; $P=0.022$ ).

While comparing only patients who had undergone interval debulking post neoadjuvant chemotherapy in the two groups (Fig. 2), PPC and OC patients had similar PFS and OS). In multivariate analysis, only suboptimal cytoreduc- 


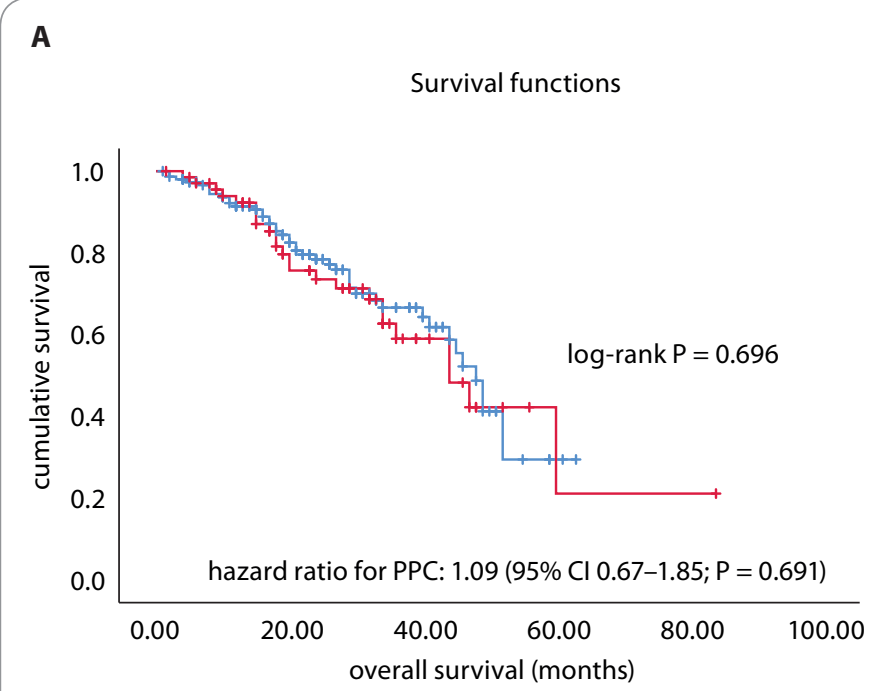

B

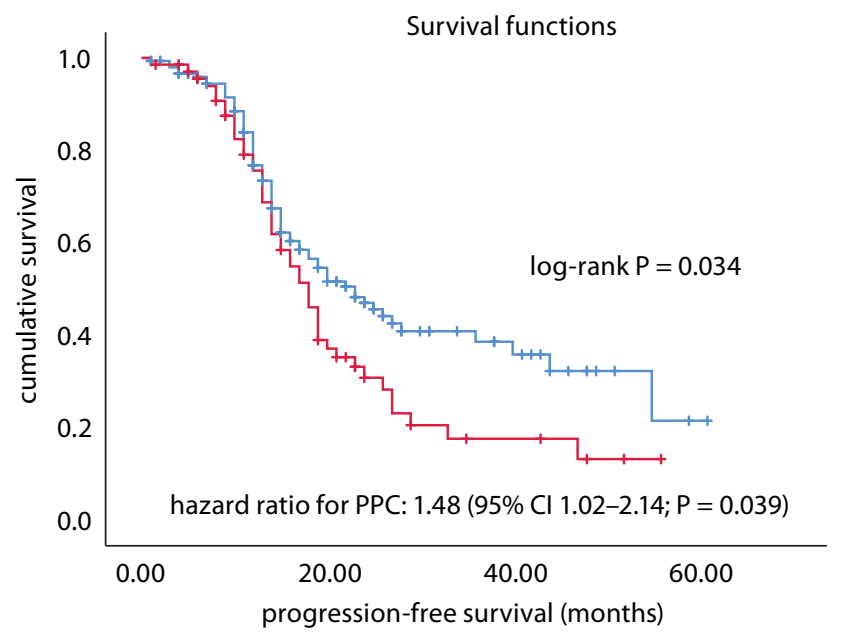

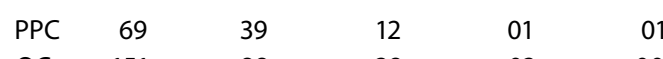

$\begin{array}{llllll}\text { OC } & 151 & 88 & 28 & 02 & 00\end{array}$

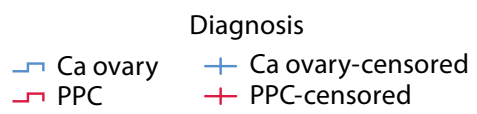

Fig. 1. Kaplan Meier curves. A) Overall survival, PPC vs. OC; B) progression-free survival, PPC vs. OC.

OC - ovarian cancer, PPC - primary peritoneal cancer

Tab. 4. Multivariate Cox regression model for overall survival and progression-free survival including prognostic factors and treatment variables found significant on univariate Cox regression model.

Site

- ovary

- peritoneum

Age

ECOG

Treatment

-PDS

- IDS

Cytoreduction

- optimal

- suboptimal

Adjuvant chemotherapy

- complete

- delayed/no

Stage

- III

- IV

ECOG - Eastern Cooperative Oncology group, IDS - interval debulking surgery, PDS - primary debulking surgery

\section{Overall survival multivariate analysis \\ HR $\quad 95 \% \mathrm{Cl}$, P-value}

1.00

1.54

1.02

1.30

$0.99-1.05,0.133$

$0.83-2.04,0.248$

\section{Progression free survival multivariate analysis
HR
95\% Cl, P-value

1.00

\begin{tabular}{l|l}
1.04 & $0.69-1.56,0.857$
\end{tabular}

$1.01 \quad 0.99-1.03,0.169$

1.00

2.18

$1.31-3.61,0.002$

$0.79-2.96,0.213$

1.00

1.42

$1.16-1.74,0.001$

1.00

1.69

$1.02-4.37,<0.001$

1.00

1.50

$1.09-2.26,0.049$ 


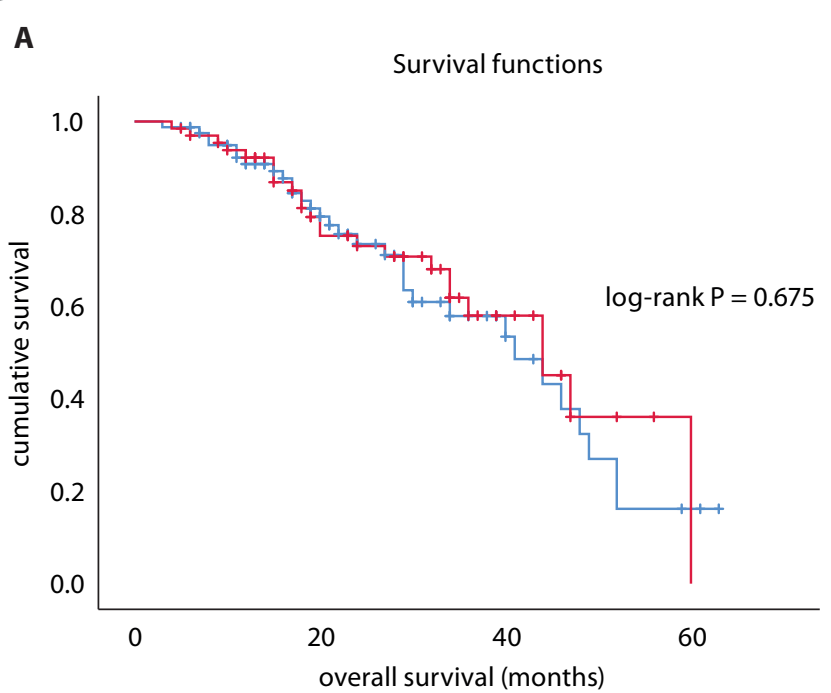

B
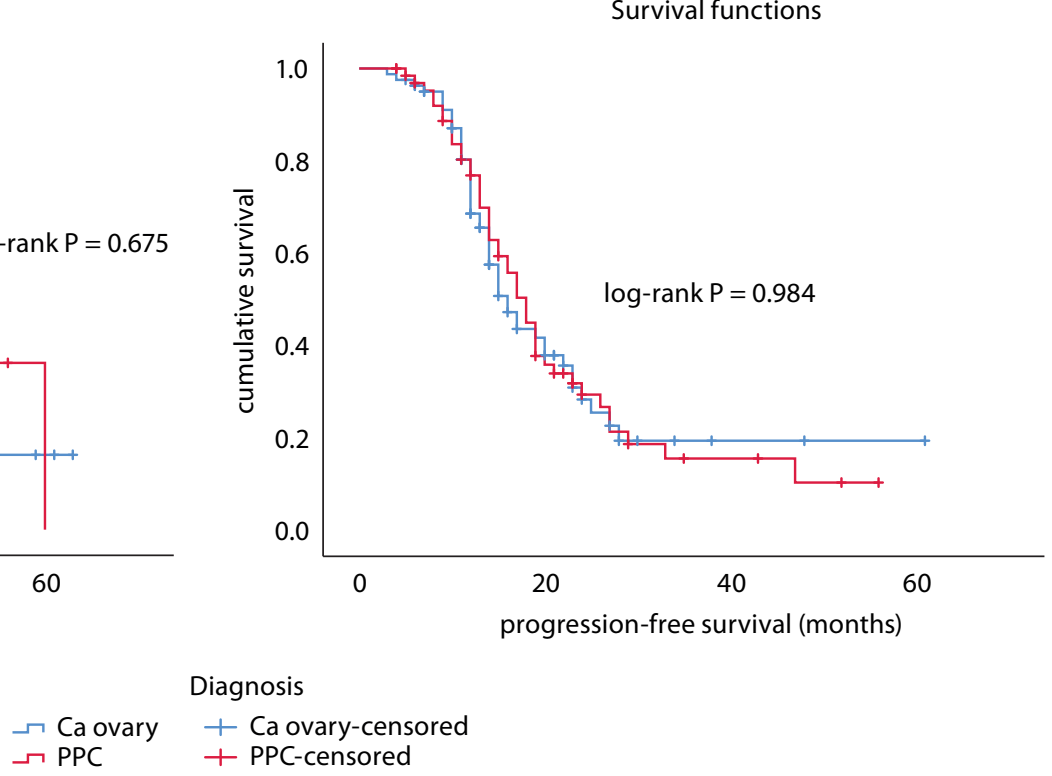

Fig. 2. Kaplan Meier curves for interval debulking surgery subgroups, ovarian carcinoma vs. primary peritoneal carcinoma. A) Overall survival; B) progression-free survival. No significant difference was seen in the survival of the two subgroups.

tion remained significantly associated with an increased risk of recurrence (HR 1.72; 95\% Cl 1.04-2.83; P = 0.035) and shorter OS (HR 2.67; $95 \% \mathrm{Cl} 1.34-$ 5.16; $\mathrm{P}=0.005)$ while increasing time interval between last neoadjuvant and first adjuvant chemotherapy increased the risk of death (HR 1.12; $95 \% \mathrm{Cl} 1.01-$ $1.25 ; P=0.040$ )

\section{Discussion}

First described by Swerdlow in 1959 [22], primary peritoneal carcinoma is still considered an enigma and one of the most challenging malignancies to treat. From the origin to the treatment response, all aspects of PPC have been a subject of immense debate and discussion. Our study explores the various aspects of PPC in an Indian population through a detailed comparative analysis with the histologically and often clinically indistinguishable advanced ovarian malignancy.

Earlier studies have favored a common embryonic origin for serous PPC and $\mathrm{OC}$ through the malignant transformation of the coelomic epithelium [2], while the recent evidence traces it back to STIC lesions in the distal fallopian tube $[5,6]$. However, several studies have found that in $30-60 \%$ of cases of both high-grade serous OC and PPC, no STIC lesions were identified despite extensive examination of the fallopian tubes $[5,7]$. We noticed in our study that nine patients had developed PPC many years after bilateral salpingo-oophorectomy was done for a benign cause. The frequency of WT1/PAX8 protein mutation was found to be similar in both groups, although different patterns of loss of heterozygosity have been quoted in the past $[5,7]$. Hence the possibility of a multifocal origin of PPC cannot be ruled out.

In this study, patients with PPC had a poorer ECOG performance status, a shorter symptom to treatment interval, and severe ascites, which was in corroboration with the existing data $[2,5,17]$. The frequency of $B R C A 1 / 2$ mutation was similar in both groups indicating that PPC could be a part of hereditary breast and $O C$ syndrome $[2,23]$.

A significantly higher number of patients (96.4\%) with PPC underwent interval cytoreduction after neoadjuvant chemotherapy compared to OC patients. A lower performance status, high volume ascites, low albumin levels, and questionable resectability of diffuse peritoneal disease precluded optimal cytoreduction of disease burden in upfront surgery [17]. The rates of optimal debulking were found to be similar in both. Though used less frequently, HIPEC post optimal interval cytoreduction was used more often in PPC patients. Considering the lack of sizeable prospective evidence, toxicity profile, and financial burden, HIPEC could be a feasible option only in a selective group of patients in primary settings and is currently recommended in interval settings with peritoneal carcinomatosis $[24,25]$.

Data on survival differences have been incongruous with some recent studies quoting an inferior overall and PFS for PPC patients, while others have not found any significant difference between the two groups. We found that although OS was similar for both groups, patients with PPC had an inferior PFS. However, on multivariate regression analysis, the primary site of origin was not a significant independent covariate. Tab. 5 highlights the survival outcomes of different comparative studies on OC and PPC, lending support to our results. Interval debulking, suboptimal cytoreduction, and higher stage increased the hazard for recurrence while residual disease $>0.5 \mathrm{~cm}$ and delayed/lack of adjuvant treatment had a significant negative impact on OS $[9,17,26,27]$. 
Tab. 5. Highlighting studies comparing survival outcomes of ovarian and primary peritoneal carcinoma corroborating with results drawn from our study.

\begin{tabular}{|c|c|c|c|c|}
\hline $\begin{array}{l}\text { Authors, year } \\
\text { of study, reference }\end{array}$ & Study design & $\begin{array}{c}N \\
(P P C \text { vs. OC) }\end{array}$ & $\begin{array}{l}\text { Overall survival } \\
\text { (PPC vs. OC) }\end{array}$ & $\begin{array}{c}\text { Progression free } \\
\text { survival (PPC vs. OC) }\end{array}$ \\
\hline $\begin{array}{l}\text { Rottmann et al, } \\
2017 \text { [9] }\end{array}$ & $\begin{array}{l}\text { case control } \\
\text { (retrospective) }\end{array}$ & 416 vs. 5,399 & $\begin{array}{c}\text { stage III/IV } \\
\text { at } 5 \text { years } 33 \text { vs. } 36.5 \%\end{array}$ & $\begin{array}{c}\text { at } 5 \text { years progression rate } \\
\text { PPC: } 67.3 \% \text {; OC: } 57.6 \%(P<0.05)\end{array}$ \\
\hline $\begin{array}{l}\text { Dubernard et al, } \\
2004 \text { [11] }\end{array}$ & $\begin{array}{l}\text { case control } \\
\text { (retrospective) }\end{array}$ & 37 vs. 37 & $\begin{array}{c}\text { at } 3 \text { years, } 60 \text { vs. } 55 \% \\
(P=N S)\end{array}$ & \\
\hline $\begin{array}{l}\text { Barda et al, } \\
2004[12]\end{array}$ & $\begin{array}{l}\text { case control } \\
\text { (prospective) }\end{array}$ & 95 vs. 117 & $\begin{array}{c}33 \text { vs. } 30 \text { months } \\
(P=N S)\end{array}$ & \\
\hline $\begin{array}{l}\text { Ayhan et al, } \\
2006[13]\end{array}$ & $\begin{array}{l}\text { case control } \\
\text { (retrospective) }\end{array}$ & 32 vs. 43 & $\begin{array}{l}30 \text { vs. } 28 \text { months } \\
\quad(P=0.35)\end{array}$ & \\
\hline $\begin{array}{l}\text { Khalifeh et al, } \\
2004 \text { [15] }\end{array}$ & $\begin{array}{l}\text { case control } \\
\text { (retrospective) }\end{array}$ & 29 vs. 96 & $\begin{array}{l}23 \text { vs. } 35 \text { months } \\
\quad(P=0.72)\end{array}$ & \\
\hline $\begin{array}{l}\text { Chao et al, } \\
2013[16]\end{array}$ & $\begin{array}{l}\text { case control } \\
\text { (retrospective) }\end{array}$ & 38 vs. 53 & & 12 vs. 16.7 months \\
\hline $\begin{array}{l}\text { Gao et al, } \\
2016[17]\end{array}$ & $\begin{array}{l}\text { case control } \\
\text { (retrospective) }\end{array}$ & 635 vs. 120 & $\begin{array}{l}31 \text { vs. } 39 \text { months } \\
\quad(P=0.007)\end{array}$ & $\begin{array}{l}11.6 \text { vs. } 13.6 \text { months } \\
\qquad P=0.012\end{array}$ \\
\hline $\begin{array}{l}\text { Eisenhauer et al, } \\
2008 \text { [19] }\end{array}$ & $\begin{array}{l}\text { case control } \\
\text { (retrospective) }\end{array}$ & 43 vs. 129 & $\begin{array}{c}\text { PPC HR: 1.54, } \\
95 \% \text { Cl 1.21-1.96 } \\
\text { P }<0.001\end{array}$ & $\begin{array}{c}\text { PPC HR 1.31; } 95 \% \text { Cl 1.07-1.61; } \\
\qquad=0.008\end{array}$ \\
\hline \multirow[t]{2}{*}{ Our study, 2021} & \multirow{2}{*}{$\begin{array}{l}\text { survival analysis } \\
\text { (retrospective) }\end{array}$} & 69 vs. 151 & 44 vs. 48 months & \multirow{2}{*}{$\begin{array}{c}18 \text { vs. } 23 \text { months } \\
\text { (HR 1.48; } 95 \% \mathrm{Cl} 1.02-2.14 \\
\mathrm{P}=0.039)\end{array}$} \\
\hline & & stage III/IV & $P=0.488$ & \\
\hline
\end{tabular}

NS - not significant, OC - ovarian carcinoma, PPC - primary peritoneal carcinoma

We did a subgroup analysis comparing PPC and OC patients with the same treatment modality, i.e. interval cytoreduction, and found similar survival rates. Suboptimal debulking significantly increased the hazard of early recurrence and death $[9,17,26]$, while a larger median time gap between last neoadjuvant and first adjuvant chemotherapy was associated with a decline in OS. The study had highly selective subject groups, including only patients of advanced stage (III/IV) serous OC and PPC. As ours was a single institutional study, uniformity of treatment/surgical protocols was maintained to minimize selection/performance bias. As per WHO 2014 classification, a diagnosis of PPC should be made on a primary surgery specimen as chemotherapy (NACT) could affect the tumor load resulting in overdiagnosis. However, considering the low number of cases over 10 years compared to serous OC and strict adherence to the GOG'93 diagnostic criteria, misdiagnosis was unlikely.
The main drawbacks of our study were:

- retrospective nature prone to information/selection bias;

- SEE-FIM protocol was not followed;

- comparing PDS and IDS groups of PPC patients was not possible as only three patients underwent upfront surgery.

\section{Conclusion}

PPC and epithelial OC has varying presentation, differing pattern at relapse and response to chemotherapy. Surgical cytoreduction following platinum-taxane based chemotherapy remains the standard treatment for PPC and advanced $O C$ with varying influence on survival. NACT followed by interval cytoreduction is a practical approach in PPC considering the widespread nature of the disease with the absence of adnexal masses and poor patient performance status. The biological basis for these differences needs to be explored to optimize treatment and improve survival outcomes. Newer treatment should look at intensification of preoperative chemotherapy beyond three cycles and use of novel agents as maintenance therapy.

\section{Acknowledgments}

We would like to acknowledge Ms. Thenmoizhi from the Department of Biostatistics and Dhanya Susan Thomas from the Department of Gynecologic Oncology for their contribution to data analysis and interpretation.

\section{References}

1. Goodman MT, Shvetsov YB. Rapidly increasing incidence of papillary serous carcinoma of the peritoneum in the United States: fact or artifact? Int J Cancer 2009; 124(9): 2231-2235. doi: 10.1002/ijc.24184.

2. Halperin R, Zehavi S, Langer R et al. Primary peritoneal serous papillary carcinoma: a new epidemiologic trend? A matched-case comparison with ovarian serous papillary cancer. Int J Gynecol Cancer 2001; 11 (5): 403-408. doi: 10.1046/j.1525-1438.2001.01027.x.

3. Connolly CF, Yahya S, Chan KK et al. Outcomes following interval debulking surgery in primary peritoneal carcinoma. Anticancer Res 2016; 36(1): 255-259.

4. Schnack TH, Sørensen RD, Nedergaard L et al. Demographic clinical and prognostic characteristics of primary ovarian, peritoneal, and tubal adenocarcinomas of serous histology - a prospective comparative study. Gynecol Oncol 2014; 135(2): 278-284. doi: 10.1016/ j.ygyno.2014.08.020 
5. Sørensen RD, Schnack TH, Karlsen MA et al. Serous ovarian, fallopian tube and primary peritoneal cancers: a common disease or separate entities - a systematic review. Gynecol Oncol 2015; 136(3): 571-581. doi: 10.1016/j. ygyno.2015.01.534

6. Chene G, Dauplat J, Radosevic-Robin N et al. Tu-be or not tu-be: that is the question... about serous ovarian carcinogenesis. Crit Rev Oncol Hematol 2013; 88(1): 134-143. doi: 10.1016/j.critrevonc.2013.03.004. Epub 2013 Mar 22. 7. Horn LC, Kafkova S, Leonhardt K et al. Serous tubal in situ carcinoma (STIC) in primary peritoneal serous carcinomas. Int J Gynecol Pathol 2013; 32(4): 339-344. doi: 10.1097/PGP.0b013e31826a629b.

8. Jordan SJ, Green AC, Whiteman DC et al. Serous ovarian, fallopian tube and primary peritoneal cancers: a comparative epidemiological analysis. Int J Cancer 2008; 122(7): 1598-1603. doi: 10.1002/ijc.23287.

9. Rottmann M, Burges A, Mahner S et al. Cancer of the ovary, fallopian tube, and peritoneum: a populationbased comparison of the prognostic factors and outcomes. J Cancer Res Clin Oncol 2017; 143(9): 1833-1844. doi: 10.1007/s00432-017-2422-6.

10. Mulhollan TJ, Silva EG, Tornos C et al. Ovarian involvement by serous surface papillary carcinoma. Int J Gynecol Pathol 1994; 13(2): 120-126. doi: 10.1097/00004347199404000-00003.

11. Dubernard G, Morice P, Rey A et al. Prognosis of stage III or IV primary peritoneal serous papillary carcinoma. Eur J Surg Oncol 2004; 30(9): 976-981. doi: 10.1016/ j.ejso.2004.08.005.

12. Barda G, Menczer J, Chetrit A et al. Comparison between primary peritoneal and epithelial ovarian carcinoma: a population-based study. Am J Obstet Gynecol 2004; 190(4): 1039-1045. doi: 10.1016/j.ajog.2003.09. 073.
13. Ayhan A, Taskiran C, Yigit-Celik N et al. Long-term survival after paclitaxel plus platinum-based combination chemotherapy for extra ovarian peritoneal serous papillary carcinoma: is it different from that for ovarian serous papillary cancer? Int J Gynecol Cancer 2006; 16(2): 484 489. doi: 10.1111/j.1525-1438.2006.00590.x

14. Schorge JO, Miller YB, Qi LJ et al. Genetic alterations of the WT1 gene in papillary serous carcinoma of the peritoneum. Gynecol Oncol 2000; 76(3): 369-372. doi 10.1006/gyno.1999.5711.

15. Khalifeh I, Munkarah AR, Lonardo F et al. Expression of Cox-2, CD34, BCl-2, and p53 and survival in patients with primary peritoneal serous carcinoma and primary ovarian serous carcinoma. Int J Gynecol Pathol 2004; 23(2): 162-169. doi: 10.1097/00004347-200404000-00011.

16. Chao KC, Chen YJ, Juang CM et al. Prognosis for advanced-stage primary peritoneal serous papillary carcinoma and serous ovarian cancer in Taiwan. Taiwan J Obstet Gynecol 2013; 52(1): 81-84. doi: 10.1016/ j.tjog.2012.10.003.

17. Gao B, Lindemann K, Anderson L et al. Serous ovarian and primary peritoneal cancers: a comparative analysis of clinicopathological features, molecular subtypes and treatment outcome. Gynecol Oncol 2016; 142(3): 458464. doi: 10.1016/j.ygyno.2016.06.023.

18. Eisenhauer EL, Sonoda Y, Levine DA et al. Platinum re sistance and impaired survival in patients with advanced primary peritoneal carcinoma: matched-case compari son with patients with epithelial ovarian carcinoma. Am J Obstet Gynecol 2008; 198(2): 213.e1-7. doi: 10.1016/j. ajog.2007.07.003.

19. Usach I, Blansit K, Chen LM et al. Survival differences in women with serous tubal, ovarian, peritoneal, and uterin carcinomas. Am J Obstet Gynecol 2015; 212(2): 188.e1-6. doi: 10.1016/j.ajog.2014.08.016.
20. Timmermans M, van der Aa MA, Lalisang RI et al. Interval between debulking surgery and adjuvant chemotherapy is associated with overall survival in patients with advanced ovarian cancer. Gynecol Oncol 2018; 150(3): 446-450. doi: 10.1016/j.ygyno.2018.07.004

21. Singh S, Guetzko M, Resnick K. Preoperative predictors of delay in initiation of adjuvant chemotherapy in patients undergoing primary debulking surgery for ovarian cancer. Gynecol Oncol 2016; 143(2): 241-245. doi: 10.1016/j.ygyno.2016.09.004.

22. Swerdlow M. Mesothelioma of the pelvic peritoneum resembling papillary cystadenocarcinoma of the ovary; case report. Am J Obstet Gynecol 1959; 77(1): 197-200. doi: 10.1016/0002-9378(59)90287-x.

23. Menczer J, Chetrit A, Barda G et al. Frequency of BRCA mutations in primary peritoneal carcinoma in Israeli Jewish women. Gynecol Oncol 2003; 88(1): 58-61. doi: 10.1006/gyno.2002.6853.

24. van Driel WJ, Koole SN, Sikorska K et al. Hyperthermic intraperitoneal chemotherapy in ovarian cancer. N Engl J Med 2018; 378(3): 230-240. doi: 10.1056/ NEJMoa1708618.

25. Klos D, Riško J, Hanuliak J et al. Peritoneal carcinomatosis from ovarian cancer - current clinical impact of cytoreductive surgery and intraperitoneal hyperthermic chemotherapy. Klin Onkol 2019; 32(5): 349-352. doi: 10.14735/amko2019349.

26. Ataseven B, Chiva LM, Harter P et al. FIGO stage IV epithelial ovarian, fallopian tube and peritoneal cancer revisited. Gynecol Oncol 2016; 142(3): 597-607. doi: 10.1016/ j.ygyno.2016.06.013

27. Chang SJ, Hodeib M, Chang J et al. Survival impact of complete cytoreduction to no gross residual disease for advanced-stage ovarian cancer: a meta-analysis. Gynecol Oncol 2013; 130(3): 493-498. doi: 10.1016/j.ygyno.2013.05.040. 